\title{
3D Surface Digitization in Scientific Research and Product Development
}

\author{
Abhinav Sood ${ }^{*}$, Varsha Dogra ${ }^{2}$, Gayatri Pathmanathan ${ }^{1}$ \\ ${ }^{1}$ Department of Anthropology, Panjab University, Chandigarh, India \\ ${ }^{2}$ Department of Environment Studies, Panjab University, Chandigarh, India \\ Email: ^abhinavsood17@gmail.com
}

How to cite this paper: Sood, A., Dogra, V. and Pathmanathan, G. (2021) 3D Surface Digitization in Scientific Research and Product Development. Forensic Medicine and Anatomy Research, 9, 11-23. https://doi.org/10.4236/fmar.2021.92002

Received: February 23, 2021

Accepted: April 6, 2021

Published: April 9, 2021

Copyright (c) 2021 by author(s) and Scientific Research Publishing Inc. This work is licensed under the Creative Commons Attribution International License (CC BY 4.0).

http://creativecommons.org/licenses/by/4.0/

(c) (i) Open Access

\begin{abstract}
This comprehensive review participates in the use of three different non-invasive surface scanning techniques directed in scientific research of medical, anthropology, archaeology forensic science, and product designing. 3D surface examining tools speak to a promising technique to provide reproducible data such as map the facial soft or hard tissues of a subject document skeletal remains, and trauma, generating 3D imitations of the components for documented and illustrative purposes while simultaneously holding exactness and unwavering quality. Three-dimensional imaging is rapidly turning into a vital tool for reconstruction and examination in scientific research. The final 3D mesh can be 3D printed or the digital version can be shared online with scientific researchers. This review manuscript highlights several studies utilizing non-invasive scanning techniques, depicts the pro and cons of the 3D scanning techniques, and different features of the scanners irrespective of the cost which would be helpful for future research work. A resourceful review was conducted using 7 databases; PubMed, CENTRAL, Science Direct, Scopus, Google Scholar, Research Gate, and IEEE Xplore from 2002 to 2020. Search terms were; "3D Laser scanning", "Photogrammetry", "Skeleton preservation", "Documentation", "Surface Scanning", etc. Papers with quality work and related to the field of forensic science, anthropometry, 3D facial scanning, and product development were selected. From all the studies, 71 studies met the eligibility criteria, and other articles were excluded which were non-relevant, had duplicate records, and did not meet search criteria. This review provides in-depth understanding and discussions into methods, restrictions, and inferences from respective research publications.
\end{abstract}

\section{Keywords}

Anthropometry, Non-Invasive, Laser Scanners, Stereophotogrammetry, Structured Light 


\section{Introduction}

Over the last three decades, there has been massive development in noninvasive $3 \mathrm{D}$ imaging techniques allowing the study of quantitative data without any extensive data reduction [1] [2]. These 3D scanning techniques structure a practical three-dimensional virtual imitation by making a point cloud of its geometry with specific software [3]. Noninvasive 3D scanners have gained popularity because of their compact designs, low cost, and updated user-friendly software. Digital 3D models have evolved as a helpful tool in research and product development. Three-dimensional (3D) surface scanners are being used continuously more by medical scientists and physical anthropologists to recreate, examine articles and human remains, including craniofacial features [4] [5] [6]. Moreover, studies based on anthropometry are useful and precise for product designing. Merchandise planning experts have recognized the requirement for progressively satisfactory estimations of human anthropometry using 3D investigative methods. Researchers have applied 3D anthropometry in structuring head and facial gear such as helmets, protective caps, goggles, and respirator covers as these objects cannot stretch like garments and other similar products [7] [8] [9]. 3D scanning is expanding materialness in quantitative assessment, for example in assessing plastic medical procedure results. 3D surface scans have been a part of numerous studies like facial reconstruction and identification for creating virtual databases, such as CAESAR, PRIMO, and NESPOS [10] [11] [12] [13] [14]. No 3D surface scanning technique produces meshes that are impeccably appropriate for all purposes. There are faults related to the creation of physical reproductions and morphometric investigation. The noticeable differences in the mesh quality of the model are influenced by the setting utilized, geometrical multifaceted nature of the object, shape, and surface features such as reflectivity and transparency [15]. The comparison of different scanners and their radiant energy shows their relative advantages and disadvantages. Few of the noninvasive surface scanners have been shown in Table 1.

\section{Types of Non-Invasive Surface Scanning}

\subsection{Laser Scanning}

There has been a substantial amount of research on laser scanning. Laser-based 3D scanners utilize a procedure called trigonometric triangulation to precisely catch a 3D shape as millions of points. Laser scanners operate by quickly transmitting a consistent laser beam when the beam hits the physical object a portion of its energy bounces back to the scanner where if the returned vitality signal is sufficient a sensor recognizes and timer utilizes it to ascertain the distance from the scanner to the object. The subsequent output is a set of 3D coordinate estimations. The utilization of laser light on human subjects is managed by the International Electrotechnical Commission standard under which only class 1 and 2 laser light sources are viewed as eye-safe beyond which higher class poses threat to both skin and eyes. Class 1 discharges light emission of fewer than 0.39 
Table 1. Common non-invasive surface scanners along with their specifications (STL-stereolithography, PLY-Stanford Polygon, OBJ-Wavefront Object, VRML-Virtual Reality Modeling Language, TSB-TriSpectives, 3D, U3D-Universal 3D, IEC-International Electrotechnical Commission, FDA-Food and Drug Administration, EOS-Electro-Optical System).

\begin{tabular}{|c|c|c|c|c|c|c|}
\hline $\begin{array}{l}\text { Model (Type } \\
\text { of Scanner) }\end{array}$ & $\begin{array}{l}\text { Next Engine } \\
\text { Scan Studio } \\
\text { HD Pro }\end{array}$ & $\begin{array}{c}\text { Minolta Vivid } \\
\text { VI910 }\end{array}$ & $3 \mathrm{dMD}$ (face) & Di3D & $\begin{array}{l}\text { EINSCAN } \\
\text { PRO (Hand } \\
\text { Held) }\end{array}$ & $\begin{array}{c}\text { Smart SCAN } \\
\text { 3DBreuckmann } \\
\text { scanner }\end{array}$ \\
\hline $\begin{array}{l}\text { Type of radiant } \\
\text { energy }\end{array}$ & $\begin{array}{l}\text { Multi Laser + } \\
\text { structured light }\end{array}$ & $\begin{array}{l}\text { Laser Class } 2 \\
\text { (IEC60825 } \\
\text { Class } 1 \text { (FDA) }\end{array}$ & $\begin{array}{l}\text { Structured light }+ \\
\text { Stereo } \\
\text { photogrammetry } \\
\text { (Active + passive) }\end{array}$ & $\begin{array}{l}\text { Stereo } \\
\text { photogrammetry } \\
\text { (Passive) }\end{array}$ & $\begin{array}{l}\text { White light LED } \\
\text { structured light }\end{array}$ & Structured light \\
\hline Hardware & $\begin{array}{l}\text { Scanner with } 5 \\
\text { MP camera, } \\
\text { AutoDrive, } \\
\text { MultiDrive, } \\
\text { PartGripper. }\end{array}$ & $\begin{array}{l}\text { Laser Emitting } \\
\text { Window, } \\
\text { Light-Receiving } \\
\text { Lens, } \\
\text { Viewfinder }\end{array}$ & $\begin{array}{l}2 \text { integrated units of } 6 \\
\text { medical-grade, } \\
\text { machine vision } \\
\text { cameras. }\end{array}$ & $\begin{array}{l}4 \text { cannon EOS 550D } \\
18 \mathrm{MP} \text {, two head } \\
\text { studio flash kit }\end{array}$ & $\begin{array}{l}\text { RGB Projector } \\
\text { center, } 2 \\
\text { monochrome } \\
\text { cameras on the } \\
\text { side }\end{array}$ & $\begin{array}{l}1.4 \text { mp color camera, } \\
\text { measurement arm } \\
\text { (optional) }\end{array}$ \\
\hline Software & $\begin{array}{l}\text { ScanStudio HD } \\
\text { Pro software }\end{array}$ & $\begin{array}{l}\text { Konica Minolta's } \\
\text { polygon editing } \\
\text { software suite }\end{array}$ & $\begin{array}{l}\text { 3dMDvultus software } \\
\text { system ( } 3 \mathrm{dMD} \text { Inc., } \\
\text { Atlanta, GA, USA) }\end{array}$ & DI3D system & EXSCAN PRO & OPTOCAT \\
\hline Accuracy & $\begin{array}{l}\text { Macro }=0.005^{\prime \prime} \\
\text { Wide: } 0.015^{\prime \prime}\end{array}$ & $\pm 1.40 \mathrm{~mm}$ & $0.2 \mathrm{~mm}$ & $0.2 \mathrm{~mm}$ & $0.1 \mathrm{~mm}$ & \pm 10 bis $50 \mu \mathrm{m}$ \\
\hline Field of view & $\begin{array}{l}\text { Macro: } 3 \times 5^{\prime \prime} \\
\text { Wide: } 10 \times 13^{\prime \prime}\end{array}$ & $\begin{array}{l}0.6-2.5 \mathrm{~m} \\
(2 \mathrm{~m} \text { for WIDE } \\
\text { lens })\end{array}$ & $\begin{array}{l}190 \text { degree face and } \\
\text { neck capture }\end{array}$ & $\begin{array}{l}180 \text { degree } \\
\text { face capture }\end{array}$ & $210 \times 150 \mathrm{~mm}$ & $90-600 \mathrm{~mm}$ diag \\
\hline Accessories & Rotating plate & $\begin{array}{l}\text { Rotating } \\
\text { plate/benchtop } \\
\text { frameset }\end{array}$ & Nil & Nil & Nil & $\begin{array}{l}\text { Rotating } \\
\text { plate/measurement } \\
\text { arm (robot) }\end{array}$ \\
\hline Scan time & $\begin{array}{l}2 \text { min per scan } \\
\text { of each facet }\end{array}$ & $\begin{array}{l}0.3 \mathrm{sec}(\mathrm{FAST} \\
\text { mode }) / \\
2.5 \mathrm{sec}(\mathrm{FINE} \\
\text { mode })\end{array}$ & 1.5 millisecond & $\begin{array}{l}\text { Length of a } \\
\text { flash } \sim 1 \mathrm{~ms}\end{array}$ & 20 frames/sec & $1 \mathrm{sec}$ \\
\hline Data interface & $\begin{array}{l}\text { STL, PLY, OBJ, } \\
\text { VRLM }\end{array}$ & $\begin{array}{l}\text { STL, } \\
\text { WRL (VRML type2) }\end{array}$ & $\begin{array}{l}\text { TSB, } \\
\text { OBJ, } \\
\text { STL, } \\
\text { WRL }\end{array}$ & $\begin{array}{l}\text { OBJ, } \\
\text { STL, } \\
\text { PLY }\end{array}$ & $\begin{array}{l}\text { OBJ, STL, } \\
\text { PLY }\end{array}$ & STL, PLY, VRML \\
\hline $\begin{array}{l}3 \mathrm{D} \\
\text { post-processing }\end{array}$ & Yes & Yes & Yes & Yes & Yes & Yes \\
\hline $\begin{array}{l}\text { Cost of scanner } \\
(\$)\end{array}$ & 3,000 & 44,000 & 89,000 & 28,000 & 5,000 & 55,000 \\
\hline
\end{tabular}

milliwatts and class 2 produces a light emission of fewer than 1 milliwatts [16]. The higher class can be utilized by researchers where there is no delicate tissue covering the specimen like in the case of dry bones [3]. Both laser and white light scanners are routinely and without limitation used on skeletal material and even ligament [17] [18]. Several studies had been done in the past few years over the use of laser scanners in the field of medical science. Some of the work had shown the numerous points of interest of laser scanners over different types of $3 \mathrm{D}$ imaging innovations as far as cost, speed, and compactness. Aside from the 
setting utilized, the nature of the subsequent model in laser scanning is influenced by the positioning of the object and the surrounding conditions [19]. For the most part, to get optimal 3D scanning results from laser scanners it is suggested to pre-calibrate the scanner and know its environmental conditions [20]. To include information about the original texture of the $3 \mathrm{D}$ model, most of the manufacturers have started to equip the scanners with an optical camera system [21].

From the digitization of small objects such as teeth to a human cranium, laser scanners such as Next Engine and Minolta Vivid 910 scanner have already been used by several anthropologists [22]. Most of these laser scanners use a motorized turntable that rotates the object in supplement divisions to complete a $360^{\circ}$ rotation. The only limiting factor such scanners have is a small scan volume which can be overcome by doing multiple scans of large objects with the use of specific software. Several researchers created great outcomes from the information gathered with the laser scanners in comparison to structured light scanners in which they pointed out noticeable differences in the mesh quality and mesh degradations of the scanned models [1] [23]. Inter-observer error studies reported were found to fluctuate from device to device [24] [25] [26]. A couple of studies have contrasted laser scanner as one of the most widely used techniques for $3 \mathrm{D}$ digitization in several fields including forensic anthropology because of its low cost, easy to understand interface, overall precision and compared the results with structured light-based scanners and found that for most purposes laser scanners are much reliable [27] [28] [29] [30] [31] [32]. It is quite important to consider the practicality of the scanner and the purpose of the study to obtain the correct mesh of the objects as few studies have indicated laser scanning apart from class 1 and 2 should not be used for full-body or face scanning. Though only a few researchers have tried integrating laser scanners with stereophotogrammetry to be viable for framework evaluation of anthropometric precision [33] [34]. Problems such as long-time, unsteadiness of the body models during the scanning process have been reported in some studies to be a limiting factor affecting the final mesh [35] [36].

\subsection{Structured Light}

Structured light scanners are relatively quicker than laser-based scanners yet they do require longer sign handling. The structured light method consists of one or two cameras at a known distance and a video projector utilized for catching 3D data using triangulation standards. The structured light utilized for 3D filtering can be white or blue and is produced by various sorts of projectors. Most usually, structured light scanners use fringe projection, Moire, and phase shift. The fringe projection has a place with organized light dynamic triangulation methods, stripes with sinusoidal amplitude variation are anticipated on a $3 \mathrm{D}$ object; the twisted example is caught and handled to assess the $3 \mathrm{D}$ shape. A moiré pattern is a progression of non-irregular direct projections onto the out- 
side of the object. They typically have a relatively little field of view and work at short proximity of 1 - 2 feet [37]. Most of the structured light scanners contain only one scanner module, they are generally limited to scanning simple surfaces as complex surfaces such as the face or full-body scan repeatedly contain holes and artifacts and are less accurate and therefore necessitate multiple scans for measurements [38] [39]. Structured light scanners are normally utilized on the estimations of facial tissue, skeletal material and even on a ligament, however, they are of restricted use for dim items or translucent/intelligent structures, for example, tooth finish [23]. White light causes no known damage for delicate or hard tissue; its utilization with human subjects is in this way unlimited. Then again, it requires stricter control of natural light, since surface scanners will in general catch the whole noticeable light range, including foundation subtleties and other undesirable sources. Relatively few studies have explained the experiences of using structured light scanners to check their performance in anthropometric measurements. Measurement accuracy is affected by aspects such as environment, hardware, software, operator, subject, and procedure [40] [41] [42]. The structured light scanners have been employed for full-body acquisition to study the anthropometric features of professional athletes for identifying sport-specific characteristics, for assessment of waist and hip circumference in women and in the fashion industry for the extraction of body measurements for customized garment size [38] [43] [44] [45]. The structured light scanner has also been tested for evaluation of measurement accuracy in objects like shoes and specimens like a skull [23] [46]. Few of the structured light scanners have seemed to have limited issues in full-body scanning because of the absence of information where parts of the body fell out of scanner sight, the hair on the body surface thus creating gaps and a slight change in the pose which hinders the result of achieving meaningful measurements [47] [48]. Studies conducted in the past few years have shown that structured light scanners have a high level of accuracy and precision [49] [50] [51] [52]. The most regularly referenced disadvantage of such equipment and technology was the significant cost [53] [54] [55] [56]. Some researchers in their respective studies utilized the structured light scanners to study the facial differences between the two population groups by creating a merged facial average of one man and one woman, for each group of population. The most common differences were noticed in the chin, nose, lips, and lower facial regions. Studies conducted also found that labeled 3D gave the most exact values, unlabeled 3D delivered less exact estimations, and it was discovered that caliper was least equipped for creating exact values. Mean estimations got from three-dimensional (3D) pictures and direct anthropologic estimations were for the most part comparative [51] [57] [58] [59].

\subsection{Photogrammetry}

Photogrammetry is a technique that depends on photos to remake three-dimensional shapes using the triangulation technique to estimate the coordinates of 
landmarks on the object to be scanned that is why it is included within the non-invasive technique. This system hence requires the identification of landmarks that are perceptible in each view. Photogrammetry a safe technique, not at all like laser scanning in which just class 1 and 2 type lasers are safe to use on human subjects. Analysts adjusted and institutionalized this system with the goal that specific anthropometric measurements could be estimated to a high level of precision like direct methods [60] [61]. The coordinates are evaluated as the points where the rays from camera position to landmark cross. The estimates are influenced by parameters characteristic for the camera, particularly its focal point amendment just as extraneous parameters like the position and direction of the camera. After capturing a known article on various occasions from different perspectives, the inherent camera parameters can be resolved. When both intrinsic and extrinsic camera parameters are evaluated, a 3D surface comprising of polygons associating the landmarks is recreated (Figure 1). A large number of different favorable circumstances that $3 \mathrm{D}$ photogrammetry brings to the table are identified with the reality that it is a type of indirect anthropometry where no physical contact is required with the subject. The recent advancement in $3 \mathrm{D}$ photogrammetric devices has led to instantaneous image capture thus minimizing error from motion artifact. The result would be identical to a 3D surface output (Figure 2). Additional means, including further object altering and streamlining, are required to set up an output record for web viewing and three-dimensional (3-D) printing (Figure 3). However, the accuracy of the 3D photogrammetry using a single camera has not yet been assessed for utilization in anthropometry.

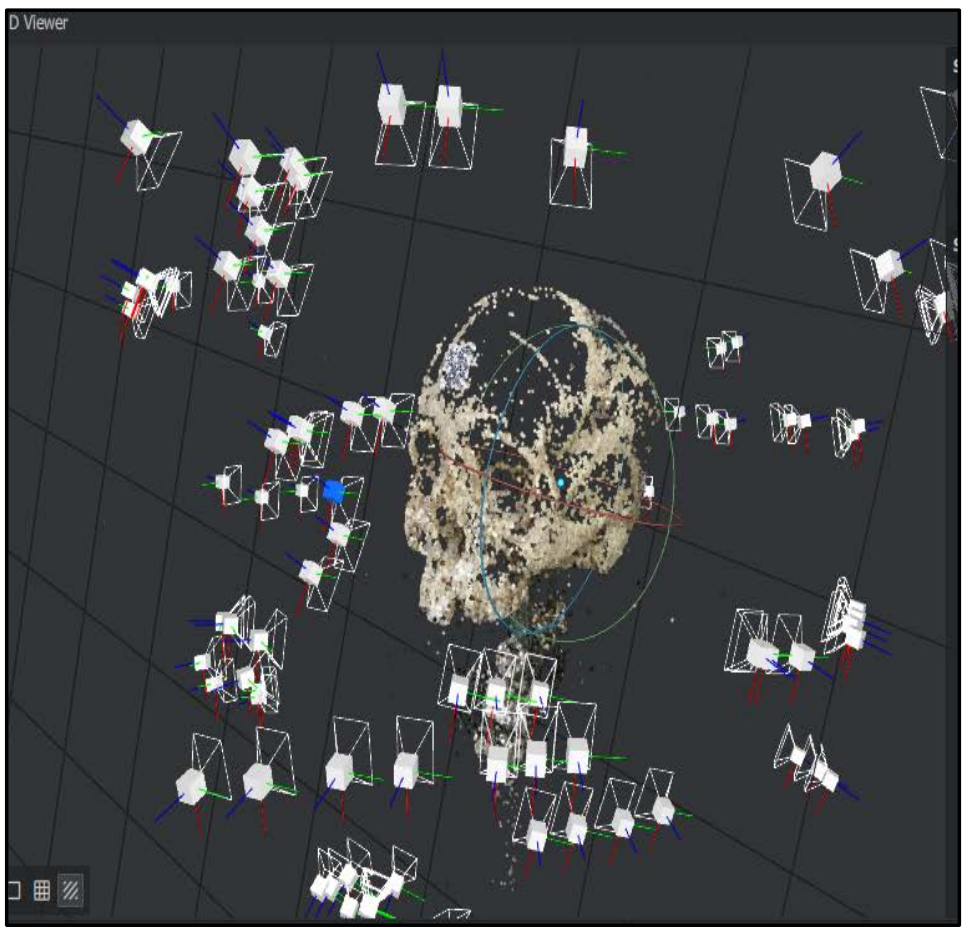

Figure 1. Initial generation of a point cloud with the location of each camera shot taken for the construction of the $3 \mathrm{D}$ mesh of cranium. 


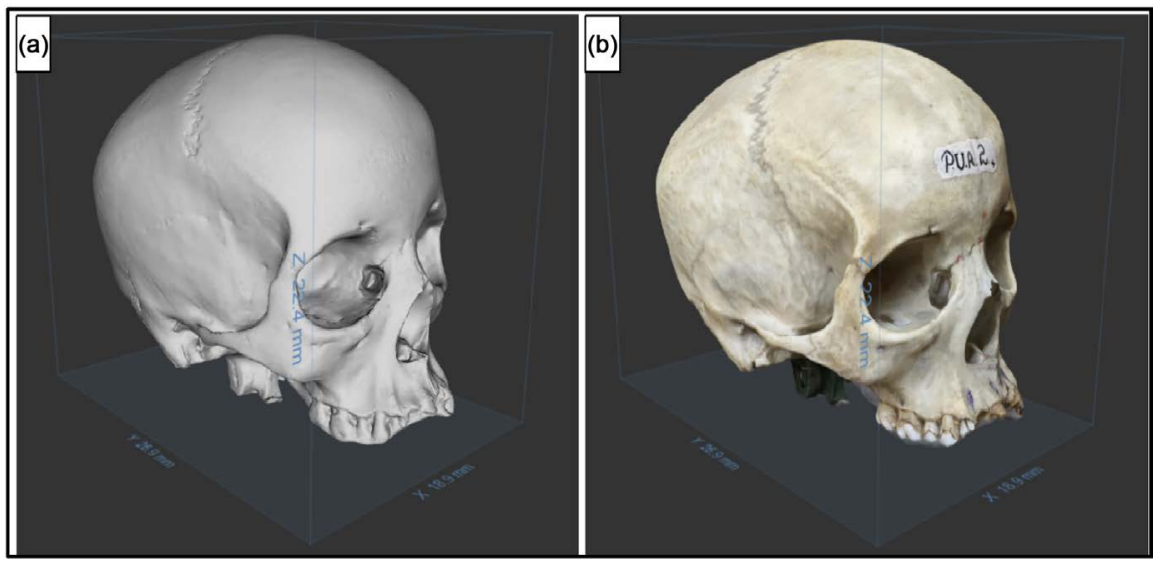

Figure 2. Screenshots of a 3D model of cranium formed using digital photos and stereophotogrammetry software. An aggregate of 300 photographs was chosen and later prepared into a photogrammetric model. The duration for the complete textured model was $3 \mathrm{hr}$.

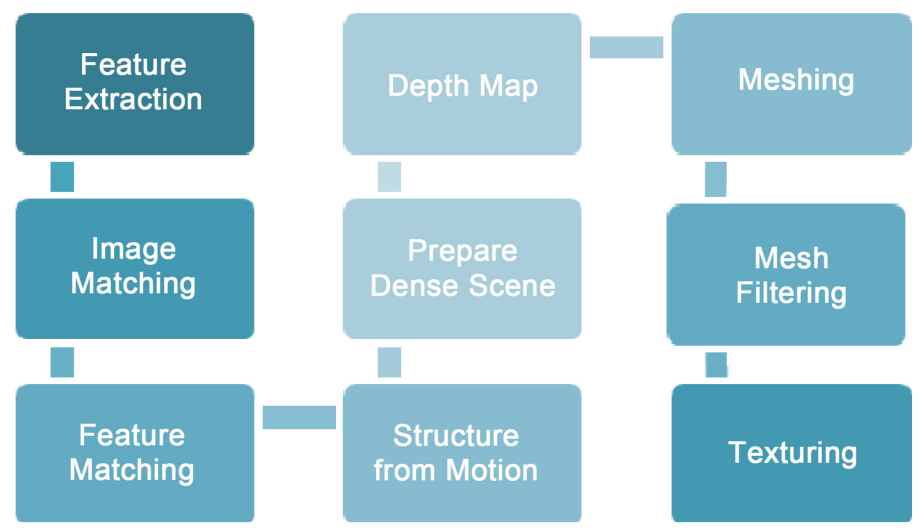

Figure 3. Three-dimensional model generation pipeline.

Resulting SfM (Structure from Motion) models were processed in Autodesk Remake 2020. These steps are automatically finished by the software and permit the scientists to pinpoint zones of poor photograph quality and angles that ought to be tended to as quickly as time permits.

The techniques have been successfully used in forensic analysis and comparison of patterned skin injuries caused by objects such as a wrench, a hammer, a tire, a shoe sole, and bite marks [62]. Few studies have been conducted using stereophotogrammetry for recording facial morphology. Recently the technique has been used to create 3D mug shot models with the end goal of visual scientific identification on pictures [63]. Right now, the prevailing method to find anthropometric landmarks depends on setting markers on the human body before scanning [64] [65] [66] [67]. Few authors infer that estimations obtained utilizing 3D photogrammetric pictures are a substantial and reproducible strategy for recording facial morphology. A very few studies had been executed on mannequins, facial plaster casts, and cadavers comparing several techniques, for example, laser scanning to assess the accuracy and reliability of standard anthropo- 
metric linear measurements to contrast their results to one another, cost of the hardware, and exactness, for applications on the human body such as post-usable assessment of medical procedures or to make custom medical devices [68] [69] [70] [71].

\section{Conclusion}

3D surface scanning devices were found to be promising devices in the digital reconstruction of facial models, artifacts, and product designing. These imaging tools have the benefits of being brisk, simple to utilize, non-obtrusive, and effectively versatile, not at all like other $3 \mathrm{D}$ hard tissue imaging frameworks which have radiation issues involved. These progressive imaging technologies offer ways to document the subject or specimen in question in exceptional detail. To achieve good results for the final mesh a lot of factors should be considered before choosing the scanning device for a particular project as sometimes even the high-end scanners are unable to give the desired results. The maximum capacity of these surface digitization techniques still can't seem to be accomplished. If it is demonstrated that $3 \mathrm{D}$ digitization techniques are a lot practical to use in the research community the hardware and software required should be open to all researchers. From the review, it can be concluded that surface digitization techniques have proved to be beneficial in scientific research and product development. Future studies are still encouraged to provide baseline findings and improve performance.

\section{Conflicts of Interest}

There's no conflict of interest.

\section{References}

[1] Friess, M. (2012) Scratching the Surface? The Use of Surface Scanning in Physical and Paleoanthropology. Journal of Anthropological Sciences, 90, 1-25.

[2] Weinberg, S.M. and Kolar, J.C. (2005) Three-Dimensional Surface Imaging: Limitations and Considerations from the Anthropometric Perspective. Journal of Craniofacial Surgery, 16, 847-851. https://doi.org/10.1097/01.SCS.0000164330.96675.0C

[3] Weber, G.W. and Bookstein, F.L. (2011) Virtual Anthropology: A Guide to a New Interdisciplinary Field. https://doi.org/10.1007/978-3-211-49347-2_1

[4] Karas, B.V. and Beaubien, H.F. (2006) Three-Dimensional Laser Scanning of Cultural Heritage: The Deer Stones of Mongolia. Scanning, 28, 187-188. http://www.ncbi.nlm.nih.gov/pubmed/16881146

[5] Park, H.-K., Chung, J.-W. and Kho, H.-S. (2006) Use of Hand-Held Laser Scanning in the Assessment of Craniometry. Forensic Science International, 160, 200-206. https://doi.org/10.1016/j.forsciint.2005.10.007

[6] Friess, M., Marcus, L.F., Reddy, D.P. and Delson, E. (2002) The Use of 3D Laser Scanning Techniques for the Morphometric Analysis of Human Facial Shape Variation. BAR International Series, 1049, 31-35.

[7] Robinette, K.M. and Whitestone, J.J. (1994) The Need for Improved Anthropome- 
tric Methods for the Development of Helmet Systems. Aviation, Space, and Environmental Medicine, 65, A95-A99. http://www.ncbi.nlm.nih.gov/pubmed/8018088

[8] Ball, R.M. and Molenbroek, J.F.M. (2008) Measuring Chinese Heads and Faces. Proceedings of the 9 th International Congress of Physiological Anthropology, $\mathrm{Hu}$ man Diversity: Design for Life, Delft, 22-26 August 2008, 150-155.

[9] Han, D.H., Rhi, J. and Lee, J. (2004) Development of Prototypes of Half-Mask Facepieces for Koreans Using the 3D Digitizing Design Method: A Pilot Study. Annals of Occupational Hygiene, 48, 707-714.

[10] Mafart, B.Y., Delingette, H. and Subsol, G. (2002) Three-Dimensional Imaging in Paleoanthropology and Prehistoric Archaeology. Archaeopress, Oxford.

https://doi.org/10.30861/9781841714301

[11] Benazzi, S., Coquerelle, M., Fiorenza, L., Bookstein, F., Katina, S. and Kullmer, O. (2011) Comparison of Dental Measurement Systems for Taxonomic Assignment of First Molars. American Journal of Physical Anthropology, 144, 342-354. https://doi.org/10.1002/ajpa.21409

[12] Baab, K.L., Ting, N.C., Capellini, T.D., Hagell, S.E. and Delson, E. (2003) Precision in 3-D Landmark Data Collection for Geometric Morphometrics. American Journal of Physical Anthropology, 120, 61-62.

[13] Harcourt-Smith, W.E.H., Tallman, M., Frost, S.R., Wiley, D.F., Rohlf, F.J. and Delson, E. (2008) Analysis of Selected Hominoid Joint Surfaces Using Laser Scanning and Geometric Morphometrics: A Preliminary Report. In: Sargis, E.J. and Dagosto, M., Eds., Mammalian Evolutionary Morphology, Springer, Dordrecht, 373-383. https://doi.org/10.1007/978-1-4020-6997-0_17

[14] Peña, I., Viktor, H.L. and Paquet, E. (2009) Finding Clothing That Fit through Cluster Analysis and Objective Interestingness Measures. International Conference on Data Warehousing and Knowledge Discovery, Linz, 31 August-2 September 2009, 216-228. https://doi.org/10.1007/978-3-642-03730-6_18

[15] Polo, M.-E. and Felicísimo, Á.M. (2012) Analysis of Uncertainty and Repeatability of a Low-Cost 3D Laser Scanner. Sensors, 12, 9046-9054. https://doi.org/10.3390/s120709046

[16] Jones, P.R.M. and Rioux, M. (1997) Three-Dimensional Surface Anthropometry: Applications to the Human Body. Optics and Lasers in Engineering, 28, 89-117. https://doi.org/10.1016/S0143-8166(97)00006-7

[17] Gu, D., Chen, Y., Dai, K., Zhang, S. and Yuan, J. (2008) The Shape of the Acetabular Cartilage Surface: A Geometric Morphometric Study Using Three-Dimensional Scanning. Medical Engineering \& Physics, 30, 1024-1031. https://doi.org/10.1016/j.medengphy.2007.12.013

[18] Aung, S.C., Ngim, R.C.K. and Lee, S.T. (1995) Evaluation of the Laser Scanner as a Surface Measuring Tool and Its Accuracy Compared with Direct Facial Anthropometric Measurements. British Journal of Plastic Surgery, 48, 551-558. https://doi.org/10.1016/0007-1226(95)90043-8

[19] Algee-Hewitt, B.F.B. and Wheat, A.D. (2016) The Reality of Virtual Anthropology: Comparing Digitizer and Laser Scan Data Collection Methods for the Quantitative Assessment of the Cranium. American Journal of Physical Anthropology, 160, 148-155. https://doi.org/10.1002/ajpa.22932

[20] Beraldin, J.A. (2004) Integration of Laser Scanning and Close-Range Photogrammetry-The Last Decade and Beyond. Proceedings 20 th ISPRS Congress 2004, Istanbul, 12-23 July 2004, 12-23. 
[21] Fangi, G., Fiori, F., Gagliardini, G. and Malinverni, E.S. (2002) Fast and Accurate Close Range 3D Modelling by Laser Scanning System. International Archives of the Photogrammetry, Remote Sensing and Spatial Information Sciences, 34, 196-203.

[22] Tocheri, M.W. (2009) Laser Scanning: 3D Analysis of Biological Surfaces. In: Advanced Imaging in Biology and Medicine, Springer, Berlin, 85-101. https://doi.org/10.1007/978-3-540-68993-5_4

[23] Slizewski, A., Friess, M. and Semal, P. (2010) Surface Scanning of Anthropological Specimens: Nominal-Actual Comparison with Low Cost Laser Scanner and High End Fringe Light Projection Surface Scanning Systems. Quartär, 57, 179-187.

[24] Sholts, S.B., Wärmländer, S.K.T.S., Flores, L.M., Miller, K.W.P. and Walker, P.L. (2010) Variation in the Measurement of Cranial Volume and Surface Area Using 3D Laser Scanning Technology. Journal of Forensic Sciences, 55, 871-876. https://doi.org/10.1111/j.1556-4029.2010.01380.x

[25] Slizewski, A. and Semal, P. (2009) Experiences with Low and High Cost 3D Surface Scanner. Quartär, 56, 131-138.

[26] Chacón, M.G., Détroit, F., Coudenneau, A. and Moncel, M.-H. (2016) Morphometric Assessment of Convergent Tool Technology and Function during the Early Middle Palaeolithic: The Case of Payre, France. PLOS ONE, 11, e0155316. https://doi.org/10.1371/journal.pone.0155316

[27] Garvin, H.M. and Stock, M.K. (2016) The Utility of Advanced Imaging in Forensic Anthropology. Academic Forensic Pathology, 6, 499-516.

https://doi.org/10.23907/2016.050

[28] Kau, C.H., Richmond, S., Incrapera, A., English, J. and Xia, J.J. (2007) Three-Dimensional Surface Acquisition Systems for the Study of Facial Morphology and Their Application to Maxillofacial Surgery. The International Journal of Medical Robotics and Computer Assisted Surgery, 3, 97-110. https://doi.org/10.1002/rcs.141

[29] Salemi, G., Canci, A., Salzani, L., Cupitò, M., Concheri, G., Meneghello, R., Savio, G. and Faresin, E. (2011) 3D High Resolution Photo Realistic Models from a Protohistoric Burial Site. XXIII CIPA Symposium, Prague, 12-16 September 2011, 1-8.

[30] Konica, M. (n.d.) Non-Contact 3D Digitizer Vivid 910/VI-910: Instruction Manual.

[31] Sansoni, G., Cattaneo, C., Trebeschi, M., Gibelli, D., Porta, D. and Picozzi, M. (2009) Feasibility of Contactless 3D Optical Measurement for the Analysis of Bone and Soft Tissue Lesions: New Technologies and Perspectives in Forensic Sciences. Journal of Forensic Sciences, 54, 540-545. https://doi.org/10.1111/j.1556-4029.2009.01041.x

[32] Kelkel, Y., Foissac, M. and Baly, L. (2010) A Simple and Standardized Method for Analyzing Head and Face Morphology of a Population Sample. 3D Body Scanning Technologies, Lugano, 19-20 October 2010, 222-228.

https://doi.org/10.15221/10.222

[33] Majid, Z., Setan, H. and Chong, A. (2008) Integration of Stereophotogrammetry and Triangulation-Based Laser Scanning System for Precise Mapping of Craniofacial Morphology. The International Archives of the Photogrammetry, Remote Sensing and Spatial Information Sciences, 37, 805-811.

[34] Fourie, Z., Damstra, J., Gerrits, P.O. and Ren, Y. (2011) Evaluation of Anthropometric Accuracy and Reliability Using Different Three-Dimensional Scanning Systems. Forensic Science International, 207, 127-134. https://doi.org/10.1016/j.forsciint.2010.09.018 
[35] Kovacs, L., Zimmermann, A., Brockmann, G., Gühring, M., Baurecht, H., Papadopulos, N.A., Schwenzer-Zimmerer, K., Sader, R., Biemer, E. and Zeilhofer, H.F. (2006) Three-Dimensional Recording of the Human Face with a 3D Laser Scanner. Journal of Plastic, Reconstructive \& Aesthetic Surgery, 59, 1193-1202. https://doi.org/10.1016/j.bjps.2005.10.025

[36] Spahiu, T., Grimmelsmann, N., Ehrmann, A., Shehi, E. and Piperi, E. (2016) On the Possible Use of 3D Printing for Clothing and Shoe Manufacture. 7 th International Conference of Textile, Tirana, 10-11 November 2016, 1-7.

[37] Mahmoudabadi, H., Shoaf, T. and Olsen, M.J. (2013) Superpixel Clustering and Planar Fit Segmentation of 3D Lidar Point Clouds. 2013 4th International Conference on Computing for Geospatial Research and Application, San Jose, 22-24 July 2013, 1-7. https://doi.org/10.1109/COMGEO.2013.2

[38] D’Apuzzo, N. (2007) 3D Body Scanning Technology for Fashion and Apparel Industry. Videometrics IX, Proceedings of SPIE-IS\&T Electronic Imaging, Vol. 6491, 64910O. https://doi.org/10.1117/12.703785

[39] Zhou, S. and Xiao, S. (2018) 3D Face Recognition: A Survey. Human-Centric Computing and Information Sciences, 8, 35.

https://doi.org/10.1186/s13673-018-0157-2

[40] Wang, M.-J.J., Wu, W.-Y., Lin, K.-C., Yang, S.-N. and Lu, J.-M. (2007) Automated Anthropometric Data Collection from Three-Dimensional Digital Human Models. The International Journal of Advanced Manufacturing Technology, 32, 109-115. https://doi.org/10.1007/s00170-005-0307-3

[41] Daanen, H.A.M. and Ter Haar, F.B. (2013) 3D Whole Body Scanners Revisited. Displays, 34, 270-275. https://doi.org/10.1016/j.displa.2013.08.011

[42] Lu, J.-M., Wang, M.-J.J. and Mollard, R. (2010) The Effect of Arm Posture on the Scan-Derived Measurements. Applied Ergonomics, 41, 236-241. https://doi.org/10.1016/j.apergo.2009.07.002

[43] Giachetti, A., Piscitelli, F., Cavedon, V., Milanese, C. and Zancanaro, C. (2015) Automatic Analysis of 3D Scans of Professional Athletes. 6th International Conference and Exhibition on 3D Body Scanning Technologies, Lugano, 27-28 October 2015, 92-97. https://doi.org/10.15221/15.092

[44] Pepper, M.R., Freeland-Graves, J.H., Yu, W., Stanforth, P.R., Cahill, J.M., Mahometa, M. and Xu, B. (2010) Validation of a 3-Dimensional Laser Body Scanner for Assessment of Waist and Hip Circumference. Journal of the American College of $\mathrm{Nu}$ trition, 29, 179-188. https://doi.org/10.1080/07315724.2010.10719832

[45] Petrak, S., Naglić, M.M. and Geršak, J. (2020) Sizing and Fit for Swimsuits and Diving Suits. In: Anthropometry Apparel Sizing and Design, Elsevier, Amsterdam, 255-287. https://doi.org/10.1016/B978-0-08-102604-5.00010-X

[46] Lovato, C., Bissolo, E., Lanza, N., Stella, A. and Giachetti, A. (2014) A Low Cost and Easy to Use Setup for Foot Scanning. 5th International Conference on $3 D$ Body Scanning Technologies, Lugano, 21-22 October 2014, 21-22.

https://doi.org/10.15221/14.365

[47] Lovato, C., Milanese, C., Giachetti, A. and Zancanaro, C. (2010) 3D Digital Anthropometry Using the BodySCAN. 1 st International Conference on $3 \mathrm{D}$ Body Scanning Technologies, Lugano, 19-20 October 2010, 259-263.

https://doi.org/10.15221/10.259

[48] Annichini, M., Arena, R., Fanini, M., Fattorel, M., Pavei, D., Tasson, D., Garro, V., Lovato, C. and Giachetti, A. (2013) Shape Processing for Digital Anthropometry. 
[49] Kau, C., Zhurov, A., Richmond, S., Cronin, A., Savio, C. and Mallorie, C. (2006) Facial Templates: A New Perspective in Three Dimensions. Orthodontics \& Craniofacial Research, 9, 10-17. https://doi.org/10.1111/j.1601-6343.2006.00359.x

[50] Kau, C.H., Richmond, S., Zhurov, A., Ovsenik, M., Tawfik, W., Borbely, P. and English, J.D. (2010) Use of 3-Dimensional Surface Acquisition to Study Facial Morphology in 5 Populations. American Journal of Orthodontics and Dentofacial Orthopedics, 137, S56.e1-S56.e9. https://doi.org/10.1016/j.ajodo.2009.04.022

[51] Ort, R., Metzler, P., Kruse, A.L., Matthews, F., Zemann, W., Grätz, K.W. and Luebbers, H.-T. (2012) The Reliability of a Three-Dimensional Photo System-(3dMDface-) Based Evaluation of the Face in Cleft Lip Infants. Plastic Surgery International, 2012, Article ID: 138090. https://doi.org/10.1155/2012/138090

[52] Aldridge, K., Boyadjiev, S.A., Capone, G.T., DeLeon, V.B. and Richtsmeier, J.T. (2005) Precision and Error of Three-Dimensional Phenotypic Measures Acquired from 3dMD Photogrammetric Images. American Journal of Medical Genetics Part $A$, 138, 247-253. https://doi.org/10.1002/ajmg.a.30959

[53] Rangel, F.A., Maal, T.J.J., Bergé, S.J., van Vlijmen, O.J.C., Plooij, J.M., Schutyser, F. and Kuijpers-Jagtman, A.M. (2008) Integration of Digital Dental Casts in 3-Dimensional Facial Photographs. American Journal of Orthodontics and Dentofacial Orthopedics, 134, 820-826. https://doi.org/10.1016/j.ajodo.2007.11.026

[54] Ladeira, P., Bastos, E., Vanini, J. and Alonso, N. (2001) Use of Stereophotogrammetry for Evaluating Craniofacial Deformities: A Systematic Review. Revista Brasileira de Cirurgia Plástica, 28, 147-155. https://doi.org/10.1590/S1983-51752013000100025

[55] Lübbers, H.-T., Medinger, L., Kruse, A.L., Grätz, K.W., Obwegeser, J.A. and Matthews, F. (2012) The Influence of Involuntary Facial Movements on Craniofacial Anthropometry: A Survey Using a Three-Dimensional Photographic System. British Journal of Oral and Maxillofacial Surgery, 50, 171-175. https://doi.org/10.1016/j.bjoms.2010.12.002

[56] Lübbers, H.-T., Medinger, L., Kruse, A., Grätz, K.W. and Matthews, F. (2010) Precision and Accuracy of the 3dMD Photogrammetric System in Craniomaxillofacial Application. Journal of Craniofacial Surgery, 21, 763-767. https://doi.org/10.1097/SCS.0b013e3181d841f7

[57] Gor, T., Kau, C.H., English, J.D., Lee, R.P. and Borbely, P. (2010) Three-Dimensional Comparison of Facial Morphology in White Populations in Budapest, Hungary, and Houston, Texas. American Journal of Orthodontics and Dentofacial Orthopedics, 137, 424-432. https://doi.org/10.1016/j.ajodo.2008.12.022

[58] Turner, W.N. (2012) Three Dimensional Comparison of Facial Morphology of a Caucasian American Population and a Native Brazilian Population. The University of Alabama, Birmingham.

[59] Aynechi, N., Larson, B.E., Leon-Salazar, V. and Beiraghi, S. (2011) Accuracy and Precision of a 3D Anthropometric Facial Analysis with and without Landmark Labeling before Image Acquisition. The Angle Orthodontist, 81, 245-252. https://doi.org/10.2319/041810-210.1

[60] Farkas, L.G. and Deutsch, C.K. (1996) Anthropometric Determination of Craniofacial Morphology. American Journal of Medical Genetics, 65, 1-4.

https://doi.org/10.1002/ajmg.1320650102

[61] Enciso, R., Shaw, A.M., Neumann, U. and Mah, J. (2003) Three-Dimensional Head Anthropometric Analysis. Proceedings of the SPIE, Vol. 5029, 590-597.

https://doi.org/10.1117/12.479752 
[62] Thali, M.J., Braun, M., Markwalder, T.H., Brueschweiler, W., Zollinger, U., Malik, N.J., Yen, K. and Dirnhofer, R. (2003) Bite Mark Documentation and Analysis: The Forensic 3D/CAD Supported Photogrammetry Approach. Forensic Science International, 135, 115-121. https://doi.org/10.1016/S0379-0738(03)00205-6

[63] Leipner, A., Obertová, Z., Wermuth, M., Thali, M., Ottiker, T. and Sieberth, T. (2019) 3D Mug Shot-3D Head Models from Photogrammetry for Forensic Identification. Forensic Science International, 300, 6-12. https://doi.org/10.1016/j.forsciint.2019.04.015

[64] Burnsides, D., Boehmer, M. and Robinette, K. (2002) 3-D Landmark Detection and Identification in the CAESAR Project. Proceedings of the Third International Conference on 3-D Digital Imaging and Modeling, Quebec, 28 May-1 June 2001, 393-398.

[65] Geisen, G.R., Mason, C.P., Houston, V.L., Whitestone, J.J., McQuiston, B.K. and Beattie, A.C. (1995) Automatic Detection, Identification, and Registration of Anatomical Landmarks. Proceedings of the Human Factors and Ergonomics Society Annual Meeting, 39, 750-753. https://doi.org/10.1177/154193129503901107

[66] Lewark, E.A. and Nurre, J.H. (1998) Automated Fiducial Labeling on Human Body Data. In: Ellson, R.N. and Nurre, J.H., Eds., Three-Dimensional Image Capture Applications, International Society for Optics and Photonics, Bellingham, 82-89. https://doi.org/10.1117/12.302440

[67] Tai, Y., Chao, S. and Yang, S. (2002) Automatic Detection and Labeling of Anatomical Landmarks on Virtual Human Model from 3D Laser Digitizer. Proceedings of the International Workshop on Advanced Image Technology (IWAIT), Huarian.

[68] Winder, R.J., Darvann, T.A., McKnight, W., Magee, J.D.M. and Ramsay-Baggs, P. (2008) Technical Validation of the Di3D Stereophotogrammetry Surface Imaging System. British Journal of Oral and Maxillofacial Surgery, 46, 33-37. https://doi.org/10.1016/j.bjoms.2007.09.005

[69] Khambay, B., Nairn, N., Bell, A., Miller, J., Bowman, A. and Ayoub, A.F. (2008) Validation and Reproducibility of a High-Resolution Three-Dimensional Facial Imaging System. British Journal of Oral and Maxillofacial Surgery, 46, 27-32. https://doi.org/10.1016/j.bjoms.2007.04.017

[70] Kook, M.-S., Jung, S., Park, H.-J., Oh, H.-K., Ryu, S.-Y., Cho, J.-H., Lee, J.-S., Yoon, S.-J., Kim, M.-S. and Shin, H.-K. (2014) A Comparison Study of Different Facial Soft Tissue Analysis Methods. Journal of Cranio-Maxillofacial Surgery, 42, 648-656. https://doi.org/10.1016/j.jcms.2013.09.010

[71] Pesce, M., Galantucci, L.M., Percoco, G. and Lavecchia, F. (2015) A Low-Cost Multi Camera 3D Scanning System for Quality Measurement of Non-Static Subjects. Procedia CIRP, 28, 88-93. https://doi.org/10.1016/j.procir.2015.04.015 